\title{
Field assessment of condition indices (nucleic acid and protein) in Mysis diluviana
}

\author{
Ora E. Johannsson ${ }^{1, *}$, Kelly L. Bowen ${ }^{1}$, Michael T. Arts ${ }^{2}$, Richard W. Smith ${ }^{3}$ \\ ${ }^{1}$ Fisheries and Oceans, Canada, Great Lakes Laboratory for Fisheries and Aquatic Sciences, 867 Lakeshore Rd., Burlington, \\ Ontario L7R 4A6, Canada \\ ${ }^{2}$ Environment Canada, National Water Research Institute, 867 Lakeshore Rd., Burlington, Ontario L7R 4A6, Canada \\ ${ }^{3}$ McMaster University, Department of Biology, 1280 Main St. W., Hamilton, Ontario L8S 4K1, Canada
}

\begin{abstract}
Mysis diluviana, the opossum shrimp, is a key link between offshore benthic and pelagic foodwebs in the Laurentian Great Lakes. Nucleic acid and protein indices (RNA/DNA, DNA/protein, \%protein, DNA/weight), which have been related to growth and protein synthesis rates, were assessed as measures of mysid condition. We examined autumn inter-annual and spatial patterns in these metrics in juvenile and adult female M. diluviana in Lake Ontario from 2001 to 2005. Males were not included because initial results of the present study indicated that larger, mature males entered a physiological decline in autumn. Nucleic acid/protein indices had a sufficient range and sensitivity to detect differences among years and habitats. In years when $M$. diluviana was in poor condition, nucleic acid and protein indices were similar to laboratory values of animals with low growth rates, values which were slightly above the nucleic acid and protein values of fasting animals. Mysids which were deemed to be in better condition in Lake Ontario had similar condition indices to those in Lake Huron. When differences existed, inshore mysids tended to be in poorer condition than offshore mysids, supporting the hypothesis that improved food resources may encourage offshore movement of mysids during the growing season. Zooplankton areal biomass, and female \% total lipids and fecundity were not correlated with the nucleic acid and protein condition indices. However, key essential fatty acids and total saturated fatty acids had significant associations with nucleic acid and protein indices; this indicates that food quality is an important determinant of condition in M. diluviana.
\end{abstract}

KEY WORDS: Mysis relicta $\cdot$ Mysis diluviana $\cdot$ Great Lakes $\cdot$ RNA $\cdot$ Monitoring $\cdot$ Lake Ontario

\section{INTRODUCTION}

In 2002, Fisheries and Oceans, Canada, in partnership with Environment Canada, initiated a monitoring program for Mysis diluviana (formerly M. relicta, Audzijonyte \& Väinolä 2005) in Lake Ontario. The lake was changing rapidly with the arrival and expansion of several aquatic invasive species: dreissenid mussels Dreissena polymorpha and D. bugensis, predatory cladocerans Bythotrephes longimanus and Cercopagis pengoi, and the round goby Neogobius melanostomus (Dermott \& Geminiuc 2003, Johannsson 2003, Dermott et al. 2005, Warner et al. 2006, Walsh et al. 2007, Wat- kins et al. 2007), all of which could potentially impact mysid populations. In the Laurentian Great Lakes (Superior, Michigan, Huron, Ontario, but excluding Erie), M. diluviana and Diporeia spp. are the dominant large native macroinvertebrates. Historically, these species funneled the majority of zooplankton and phytoplankton production to the fish community in the offshore regions. In the 1990s, M. diluviana consumed as much, or more, of the offshore zooplankton production in Lake Ontario as the dominant planktivore, the alewife Alosa pseudoharengus (Gal et al. 2006). In 1990, prior to the invasive species impacts, mysids composed $\sim 20 \%$ of the biomass consumed by alewife 
in spring and fall (Rand et al. 1995). Dreissenid mussels now also help to move phytoplankton production to the fish community in Lakes Ontario, Erie, Michigan and Huron, where they are replacing Diporeia spp. (Dermott et al. 2005, McNickle et al. 2006, Nalepa et al. 2006). In response, the distributions and diets of fish such as alewife and lake whitefish Coregonus clupeaformis have been shifting, and diets have been broadening to include alternative prey such as dreissenids and mysids $\left(\mathrm{O}^{\prime}\right.$ Gorman et al. 2000, Pothoven et al. 2001, Hoyle et al. 2003, Hondorp et al. 2005). Mysids are also an important component of the diet of a recent invader, the round goby (Walsh et al. 2007). With the loss of Diporeia and the arrival of round goby, the role of $M$. diluviana in the offshore food web is enhanced.

The ongoing monitoring program examines the mysid population throughout Lake Ontario in late October to early November, when the best estimates of density and biomass are obtained and when the population is reproducing (Johannsson 1992, 1995). In the spring, when the water column is totally mixed, mysids feed equally well at the bottom (in the $2 \mathrm{~m}$ of water above the bottom sediment not sampled by the net) and in the upper water column (Johannsson et al. 2001). Many individuals do not undertake vertical migrations at this time, rendering estimates of abundance and biomass unreliable. In summer and fall however, the majority of the mysid diet is upper water column zooplankton. Thus, reliable estimates of abundance and biomass can be obtained at least until fall turnover in December. The generation time of Mysis diluviana in Lake Ontario is 2 yr. The principal reproductive period commences in early October and young are carried until mid-winter or early spring. In autumn, mature $M$. diluviana contain 20 to $40 \%$ lipids by dry weight (dry wt) (Adare \& Lasenby 1994). Thus, fecundity and \% total lipid content at maturity can also be monitored in the fall.

A physiological measure of mysid condition as an early warning indicator of poor health or poor food quality or availability was a desirable addition to the ecological parameters in our monitoring program. In this respect, growth rate is an excellent integrative measure of condition in organisms. While it is not possible to determine the growth rate of individuals in an annual survey, biochemical indices, such as nucleic acid and protein ratios, correlate with growth rate and hence can serve as surrogate measures of growth.

Growth rates and protein synthesis rates in both vertebrates and invertebrates have been correlated with ribonucleic acid (RNA) content or ratios of ribonucleic acid/deoxy- ribonucleic acid (RNA/DNA) (Buckley 1979, Houlihan et al. 1993, Bergeron 1997, Dahlhoff \& Menge 1996, Saiz et al. 1998, Wagner et al. 1998, 2001). In order to make comparisons between groups, total RNA must be normalized to a single cell or to a measure of body size, usually expressed as total DNA $i$ hence, the frequent use of the RNA/DNA ratio. Larger cells, which contain more structural protein, tend to be metabolically more active and have more RNA than smaller cells (Schmidt \& Schibler 1995). Consequently, protein/DNA-a measure of cell size-has also been observed to correlate with growth rates (Foster 1990). If more active cells are larger, then there should be fewer of them per unit body weight, and therefore, DNA/dry wt and DNA/carbon content have been suggested as additional measures of condition (Bergeron 1997). In laboratory studies of Mysis diluviana growth rates under different conditions, Johannsson et al. (2008) observed corresponding increases in RNA and protein relative to DNA and of protein relative to wet weight (\%protein) with increases in growth rate, while the number of cells per unit of weight (DNA per unit wet weight) decreased. Changes in temperature can alter the relationship between RNA and growth rate. RNA is more efficient at higher temperatures, and concentrations of RNA decline as temperatures increase (Buckley 1982, Foster et al. 1992). We propose that all 4 indices (RNA/DNA, protein/DNA, \%protein, DNA/weight) should be examined simultaneously when assessing changes in growth rate (Fig. 1).

Therefore, the primary purpose of the present study was to assess the potential usefulness of these nucleic acid and protein indices in monitoring the condition of Mysis diluviana in the field. This includes: (1) examining the range of inter-annual variation in the indices, (2) determining whether spatial variability is important and, if present, its patterns and consistency, (3) comparing field and experimental indices for M. diluviana,

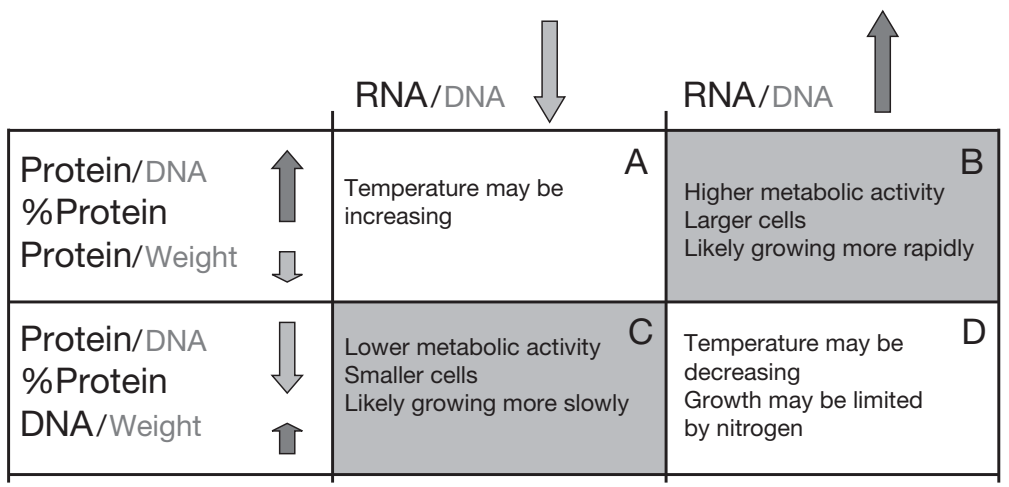

Fig. 1. Interpretation of nucleic acid and protein indices to determine relative condition factors. If the ratios are analyzed using ANCOVA, the black component of the index is the dependent variable and the gray component is the covariate. Arrows indicate direction of change of parameters 


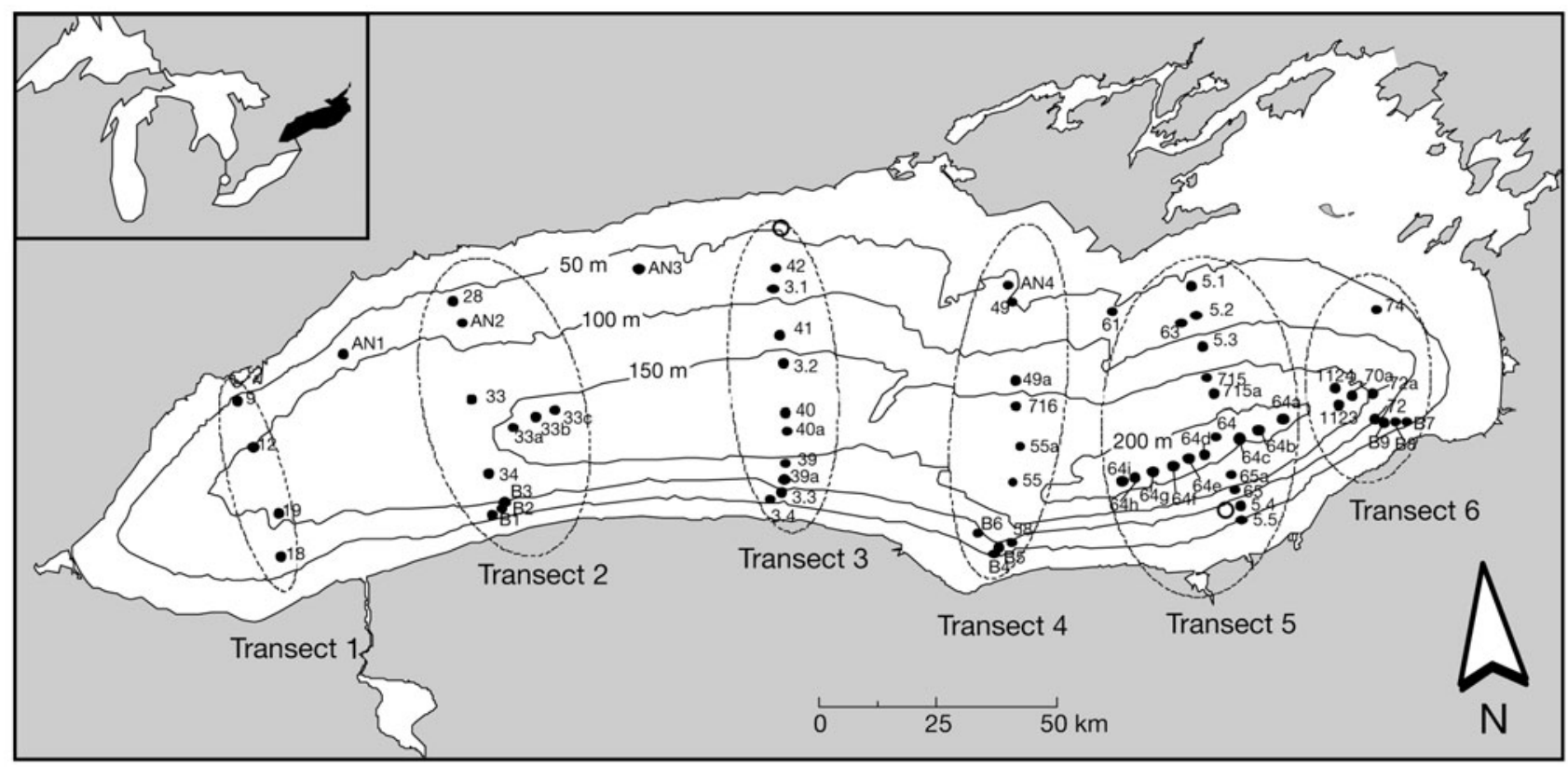

Fig. 2. Map of the 2001 to 2005 sampling stations in Lake Ontario showing the 6 cross-lake transects, the transect down the length of the deep hole, and additional stations (AN series and B series) used to augment samples in the depauperate 50 to $100 \mathrm{~m}$ bottom depth region. o: 2 shallow stations sampled only in 2001

and (4) comparing the response of the indices to other measures of mysid condition, i.e. fecundity, total lipid (mature, non-gravid females) and omega-3 essential fatty acid (EFA) concentrations (Schlechtriem et al. 2008a). By examining these growth indices along the inshore-offshore mysid abundance gradient, we assessed whether the actively maintained pattern of increasing mysid density with depth, especially of larger animals, might be a response to better conditions in offshore areas.

\section{MATERIALS AND METHODS}

Field studies. The nucleic acid and protein indices, lipid and zooplankton data were generated during 2 studies on Lake Ontario. The first, carried out in October 2001, collected mysids from 4 sites: 2 in the central region of the lake at $128 \mathrm{~m}$ (Station 41 ) and at $45 \mathrm{~m}$ (open circle north of Station 41) bottom depth, and 2 in the southeastern portion of the lake at $118 \mathrm{~m}$ (Station 65) and $63 \mathrm{~m}$ (open circle south of Station 65) bottom depth (Fig. 2).

The second ongoing study, of which the 2003 to 2005 data are reported here, monitors the Mysis diluviana population in Lake Ontario between late October and early November (Table 1). No zooplankton or nucleic acid data are available for 2002. Mysids were sampled along a total of 6 north-south transects, weather permitting, replicating the 1990 mysid sampling pattern of
Johannsson (1995) (Fig. 2). Sampling stations were located such that 10 stations fell within each of the $50 \mathrm{~m}$ bottom depth ranges except for 0 to $50 \mathrm{~m}$, and equal numbers of stations occurred in each quadrant of the lake. An additional transect was conducted through the 'deep hole' to adequately sample the 200 to $250 \mathrm{~m}$ depth range. Additional stations were added in the 50 to $100 \mathrm{~m}$ depth range where mysid densities were very low (Fig. 2).

Mysids were collected by vertical net haul at night. A rectangular, $1 \mathrm{~m}^{2}$ net constructed of $1 \mathrm{~mm}$ Nitex mesh with a $250 \mu \mathrm{m}$ cod end was lowered to within $2 \mathrm{~m}$ of the bottom, allowed to rest for $30 \mathrm{~s}$ to enable the mysids to redistribute, and then raised at $0.33 \mathrm{~m} \mathrm{~s}^{-1}$. All samples were collected between $1 \mathrm{~h}$ after dusk and $1 \mathrm{~h}$ before dawn. The net was fitted with a darkened plastic bottle at the cod end to ensure that the mysids remained in cold water and were not compressed on their ascent through the water column. Mysids were kept cool and

Table 1. Sampling dates and number of stations sampled annually for Mysis diluviana in Lake Ontario. Data originated from 2 different programs (2001 and 2003 to 2005); during the later study, stations were distributed across the lake

\begin{tabular}{|llc|}
\hline Year & Date range & Stations \\
\hline 2001 & 2 to 3 October & 4 \\
2003 & 27 to 30 October & 55 \\
2004 & 26 to 28 October & 26 \\
2005 & 7 to 12 November & 47 \\
\hline
\end{tabular}


examined immediately. Gravid females were placed individually in $0.5 \mathrm{ml}$ bullet tubes containing $8 \%$ sugar-buffered formalin. Mysids for lipid or nucleic acid and protein analyses were sexed, assigned to 1 of 3 size groups ( 4 to $8 \mathrm{~mm}, 9$ to $12 \mathrm{~mm}, \geq 13 \mathrm{~mm}$ body length) and frozen in cryovials in liquid nitrogen, either individually for nucleic acid and protein analyses or in small groups (10 to 30,5 to 10,3 to 5 animals per vial for the 3 size classes, respectively) for lipid analyses. However, mysids in the smallest size group were often not abundant enough for fatty acid analyses. The samples were stored at $-85^{\circ} \mathrm{C}$ until analysis. The remaining mysids were preserved in $8 \%$ sugarbuffered formalin.

In the 2001 study, 2 vertical zooplankton tows through the hypolimnion were conducted using a $64 \mu \mathrm{m}$ mesh closing net at each of the deeper stations. In the 2003 to 2005 study, two $153 \mu \mathrm{m}$ mesh zooplankton tows were conducted during the day through the entire water column at 6 to 9 locations spaced east to west, along transects running above and below the centre line of the lake. The positions of the sites were not fixed but opportunistic, with the intent of capturing all regions of the lake inhabited by mysids, both shallow and deep.

Zooplankton analyses. The 2 samples from each site were combined and analyzed to species level using a randomized, weighted counting procedure to ensure adequate counting of rare species (Cooley et al. 1986). Biomass was calculated from length-weight relationships derived from the literature (Johannsson et al. 2000). The areal biomass of the water column was calculated in toto. The 2001 hypolimnetic biomass data were extrapolated to the entire water column for comparison with the biomass estimates from the later years. The 2001 biomass calculations may underestimate total zooplankton, and, in particular, cladoceran biomass. Zooplankton biomass is greater per cubic meter in the epilimnion than in the meta- and hypolimnion in the fall at deep stations (data reworked from appendices, in Mills et al. 2006).

Nucleic acid and total protein determination. RNA and DNA contents of individual mysids were determined spectrophotometrically using the UV dual absorbance method (232 and $260 \mathrm{~nm}$ ) according to the protocols developed by Schmidt \& Thannhauser (1945) and modified by Munro \& Fleck (1966) and Buckley \& Bulow (1987). The method is described in detail in Schlechtriem et al. (2008b). These methods have been used for fish, crustacean and mammalian assays, and the advantages, in terms of accuracy, have been summarized by Smith et al. (1999). For example, RNA recovery efficiencies are between $95.4 \%$ (Mathers et al. 1993) and $100 \%$ (Munro \& Fleck. 1966). Two standards prepared previously from fresh and frozen Lake Ontario mysids and stored at $-85^{\circ} \mathrm{C}$ were run with each batch of samples to check consistency of sample processing.

Protein was determined using the method of Lowry et al. (1951). Standard 5-point concentration curves were created with bovine serum albumin.

Lipid determinations. Total lipid content and fatty acid methyl esters (FAME) of freeze-dried Mysis diluviana were obtained in a 3-step process: extraction and weighing of 2 subsamples for total lipid estimation, derivatization of the remainder, and quantification of FAME on a gas chromatograph (GC) as in Schlechtriem et al. (2008a). A 37-component FAME standard (Supelco \#47885-U) was used to identify FAME by comparison of retention times. The FAME of interest to this study were: (1) eicosapentaenoic acid (EPA; 20:5n-3) and docosahexaenoic acid (DHA; 22:6n-3), 2 essential fatty acids (EFA) needed for proper immunological (EPA) and neurological (DHA) function, (2) their precursor $\alpha$-linolenic acid (ALA; 18:3n-3), and (3) the sum of saturated fatty acids (SAFA; a source of energy).

Statistical treatment of data. Data are reported as mean \pm 2 SE and a significance level of $p \leq 0.05$ was used throughout unless otherwise noted. All statistical analyses were performed with SYSTAT (11.0).

The nucleic acid and protein indices examined were RNA/DNA, protein/DNA, \%protein and DNA/wet weight. The ratios change with body size in mysids (Nordin 2005, Schlechtriem et al. 2008b), with the exception of \%protein, and thus must be standardized to a common body size before they can be compared across 'treatments' (years, lakes, locations, etc.). The ratios already contain a measure of body size (DNA or weight), and thus, the indices are more sensitive if the ratios are split into their component parts (e.g. RNA vs. DNA instead of RNA/DNA vs. weight) for analysis because there is one less source of error variability. In addition, interaction terms between body size and factors are often significant when the indices are expressed as ratios, but not when the indices are split. All data were examined and, if necessary, transformed to ensure linearity and homogeneity. This meant that we examined log RNA and log protein relative to log DNA, and DNA ${ }^{2}$ relative to wet weight (females only).

Juveniles and adults exhibited considerable morphological overlap when the division was defined purely by body length. Females were first identified at a DNA content of $23 \mu \mathrm{g}$ ind. ${ }^{-1}$. However, the variability and slope of the relationship between log RNA and log DNA changed at a DNA content of $26 \mu \mathrm{g}$ ind. ${ }^{-1}$. Therefore, for analytical purposes, juveniles were defined as having a DNA content $\leq 26 \mu$ ind $^{-1}$, while adults had DNA content $>26 \mu$ ind $^{-1}$. There was no break in the data between the 2 juvenile size classes; therefore, they were combined.

The indices were first examined for variability among years using ANCOVA, or ANOVA for \%protein. Tukey's 
honestly significant difference (HSD) multiple comparison test was employed to determine significant differences between pairs of years. Next, the indices were examined for differences between inshore and offshore habitats within each year, again using ANCOVA or ANOVA. The division between inshore and offshore was set at $120 \mathrm{~m}$ bottom depth, based on the distribution of the benthic invertebrate and fish communities. In order to directly compare data that included both annual and, when significant, inshore and offshore estimates of adjusted means, we divided them into yeardepth categories; i.e. 2001-Inshore, 2001-Offshore, 2003Inshore, etc., and reanalyzed the data to produce comparable, adjusted means across the years. Finally, we compared our yearly indices from Lake Ontario with those from Lake Huron (October 2002) and with from laboratory experiments during which mysid growth rates were measured using the same methods as in the present study (Johannsson et al. 2008). The Lake Huron data were included to provide a reference to mysid nucleic acid and protein indices from another field site because the higher growth rates observed in the field have not yet been attained in laboratory experiments. These data were included directly in the ANCOVA and ANOVA analyses. The experimental data did not include mysids from as wide a size range as the field data. Therefore, we ran a separate analysis restricting the size range of the field-caught animals to match that of the experimental animals (high growth treatments, $<7^{\circ} \mathrm{C}$ ). A correction was then calculated for the experimental data by subtracting the adjusted means of the indices for the same-size selected field data from those determined for the entire set of field data. This difference was then added to the adjusted means of the experimental data so that they could be compared visually with the complete Lake Ontario data.

Upwelling events during the summer and fall often push colder waters into the northwest and southwest of the lake, decreasing epilimnetic productivity in this region through thinning of the epilimnion and increasing it in the southeast, which then has a deeper epilimnion (Patalas 1969, Johannsson 2003). Other factors, such as the Niagara River inflow along the south shore, and differential depth gradients between the north and south shores, also affect habitat characteristics in the different regions of the lake. Therefore, we divided the lake into 4 quadrants: NW, NE, SE and SW. This allowed us to examine the importance of possible habitat differences through the analysis of the association of geoposition with the nucleic acid and protein indices, both within each year and across all years, using ANCOVA or ANOVA.

To assess possible associations between EFA and nucleic acid and protein indices, Pearson correlation coefficients were calculated.

\section{RESULTS}

\section{Nucleic acid and protein indices}

Nucleic acid and protein index relationships differed between males and females. Male DNA content was $8 \%$ higher than that of females (Fig. 3A). The relationship between log RNA and log DNA also differed between the sexes (Fig. 3B), being positive and significant in females and non-existent in males. When RNA was plotted against protein, males separated into 2 groups at a protein content of $3.8 \mathrm{mg}$ ind. ${ }^{-1}$ (Fig. 3C). The separation was associated with body size: the group of males with lower RNA (cov protein) values was generally > $35 \mathrm{mg}$ wet weight and the group with higher values $<35 \mathrm{mg}$ wet weight. The RNA/DNA ratios of the larger males were also lower (1.55 to 2.05) than those of the smaller males (2.0 to 2.5) (Fig. 3D). However, the ratios normally increase with body size (Schlechtriem et al. 2008b, Fig. 3D). For these reasons, we concluded that males were in physiological decline. Consequently, males were not collected after 2003 and only females and juveniles were analyzed for inter-annual and spatial patterns.

Relatively consistent trends were observed across years in juveniles and females. Adjusted means of log RNA with log DNA as the covariate (cov log DNA), log protein (cov log DNA), and \% protein (for females only) were higher in 2003 and 2005, while adjusted means of DNA $^{2}$ (for females) or DNA (for juveniles) with weight as the covariate (cov weight) were lower (Fig. 4). An exception was log RNA (cov log DNA) in juveniles in 2005, which was intermediate and similar to that of individuals from the offshore area in 2004. The reverse was true for 2001 and 2004. The adjusted means of log RNA (cov log DNA) and log protein (cov log DNA) of offshore juveniles in 2003 were particularly high (Fig. 4A,B), while that of DNA (cov wet weight) was particularly low (Fig. 4D). The adjusted means of the later 2 indices (log protein, cov $\log$ DNA and DNA, cov wet weight) were similar to those observed in Lake Huron (Fig. 4B\&D). Juvenile adjusted mean log RNAs in Lake Ontario were significantly lower than those in Lake Huron (Fig. 4A). The experimental data indices of Johannsson et al. (2008) were similar to those observed in 2001 and 2004 in all cases (Fig. 4A): log RNA (cov log DNA) experimental data were also similar to 2005 data. These results place the condition of juvenile mysids in 2003 in Box (B) of Fig. 1. The condition of mysids in 2005 is also in Box (B); however, it would be ranked lower than 2003 based on the slightly lower log RNA (cov log DNA) and log protein (cov log DNA). The condition in 2001 was similar to that in 2004 and both fell in Box (C) of Fig. 1.

All 4 nucleic acid and protein indices of females were similar in 2003 and 2005, and in 2001 and 2004. In 

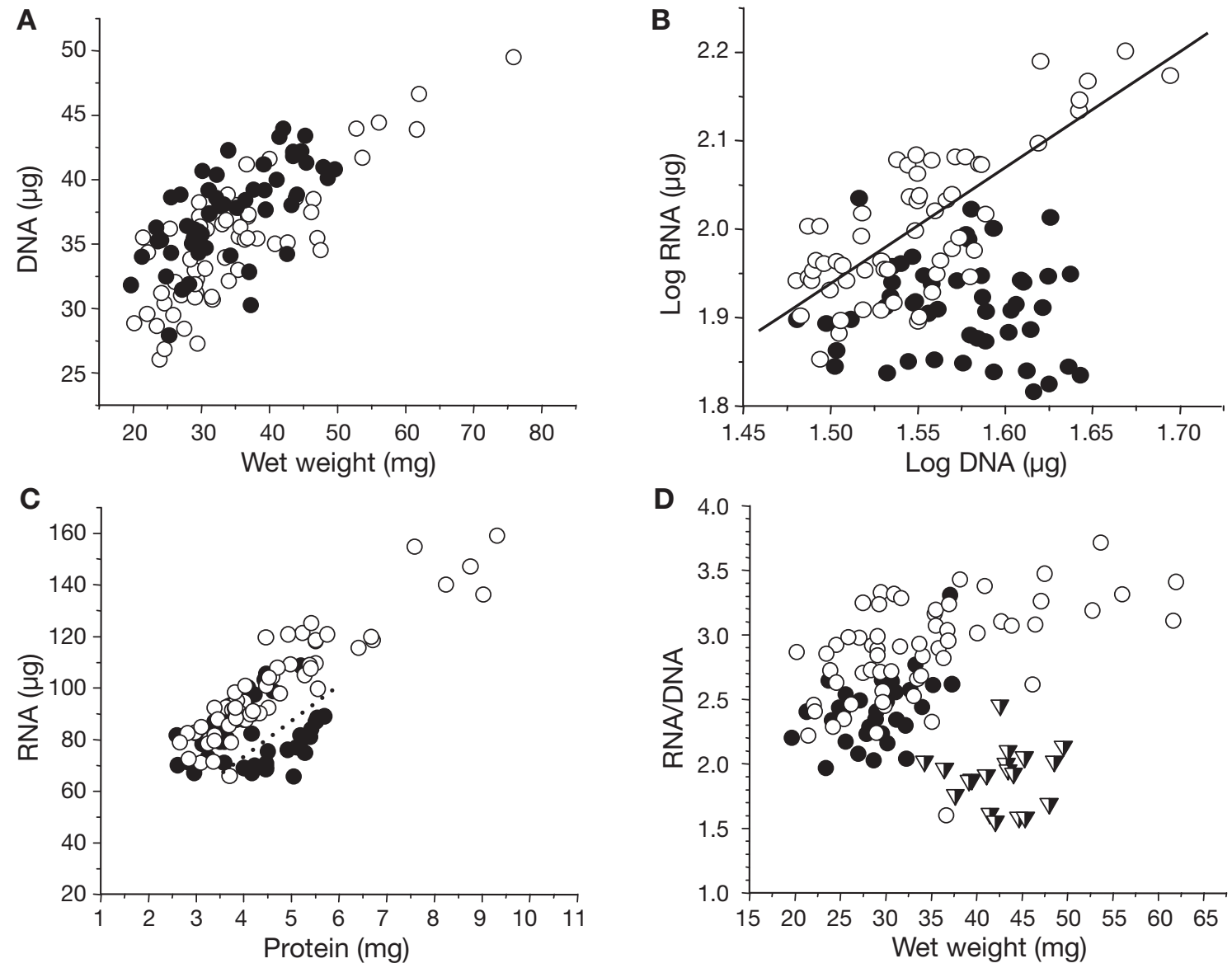

Fig. 3. Mysis diluviana. Nucleic acid and protein indices of male and female individuals in autumn. (A) Relationships between DNA content $(\mu \mathrm{g})$ and wet weight $(\mathrm{mg})$ of males $(\bullet)$ and females (०). (B) log RNA $(\mu \mathrm{g})$ vs. log DNA ( $\mu \mathrm{g})$ of males $(\bullet)$ and females (O). No relationship exists in males. For females, log RNA $=0.0283+1.312 \log \mathrm{DNA}(\mathrm{r}=0.775, \mathrm{p}<0.001$, $\mathrm{n}=58)$. Data suggest one misidentification of a male. (C) RNA ( $\mu \mathrm{g})$ vs. protein $(\mathrm{mg})$ content of males $(\bullet)$ and females $(0)$. Dotted line indicates separation of males into 2 groups. Females overlap with the higher RNA group of males. (D) RNA/DNA ratio vs. wet weight (mg) of females (O) and both groups of males defined in $(\mathrm{C})$, with high RNA/protein ratio males $(\bullet)$, low RNA/protein ratio males $(\nabla)$

females, all 3 adjusted means and \%protein in 2003 were similar to those in 2005 (Fig. 4E-H). In addition, the 2003 and 2005 values of $\log$ RNA, log protein and \%protein were similar to those in Lake Huron (Fig. 4E-G): the Lake Huron adjusted mean DNA ${ }^{2}$ was lower than that in Lake Ontario (Fig. 4H). Again, the experimental data indices of Johannsson et al. (2008) were similar to the Lake Ontario indices for femals in 2001 and 2004 (Fig. 4E-H). The condition of female mysids in 2003 and 2005 was similar and fell in Box (B) of Fig. 1, while the condition of female mysids in 2001 and 2004 was similar and poorer than in 2003 and 2005; thus, they fell in Box (C) of Fig. 1.

Inshore-offshore trends were clearly identified only in 2003 and 2004. In 8 of the 9 instances where significant differences between inshore and offshore areas occurred in the indices, the mysids were in better condition in the offshore areas; that is, the adjusted means of log RNA (cov log DNA), log protein (cov log DNA) and \%protein were higher offshore while DNA (cov weight) was lower (Fig. 4A-D, F\&G). Only 2004 juvenile log RNA did not follow this pattern (Fig. 4A).

Fig. 4. Mysis diluviana. Nucleic acid and protein indices in juvenile (A-D) and adult female (E-H) individuals (autumn adjusted means \pm 2 SE). In all cases, Lake Ontario indices $(\bullet)$ for each year (O-01, O-03, O-04, O-05 for years 2001 to 2005) are compared with autumn indices from Lake Huron $(\star)$ from $2002(\mathrm{H}-02$,$) and with laboratory experimental indices (\varangle)$ with known growth rates (Exp; data from Johannsson et al. 2008). See text for details of experimental animals. Where inshore and offshore values were significantly different, they are displayed separately: inshore (०), offshore (•). Significantly different values have been assigned different letters $(\mathrm{a}, \mathrm{b}, \mathrm{c}, \mathrm{d})$ 

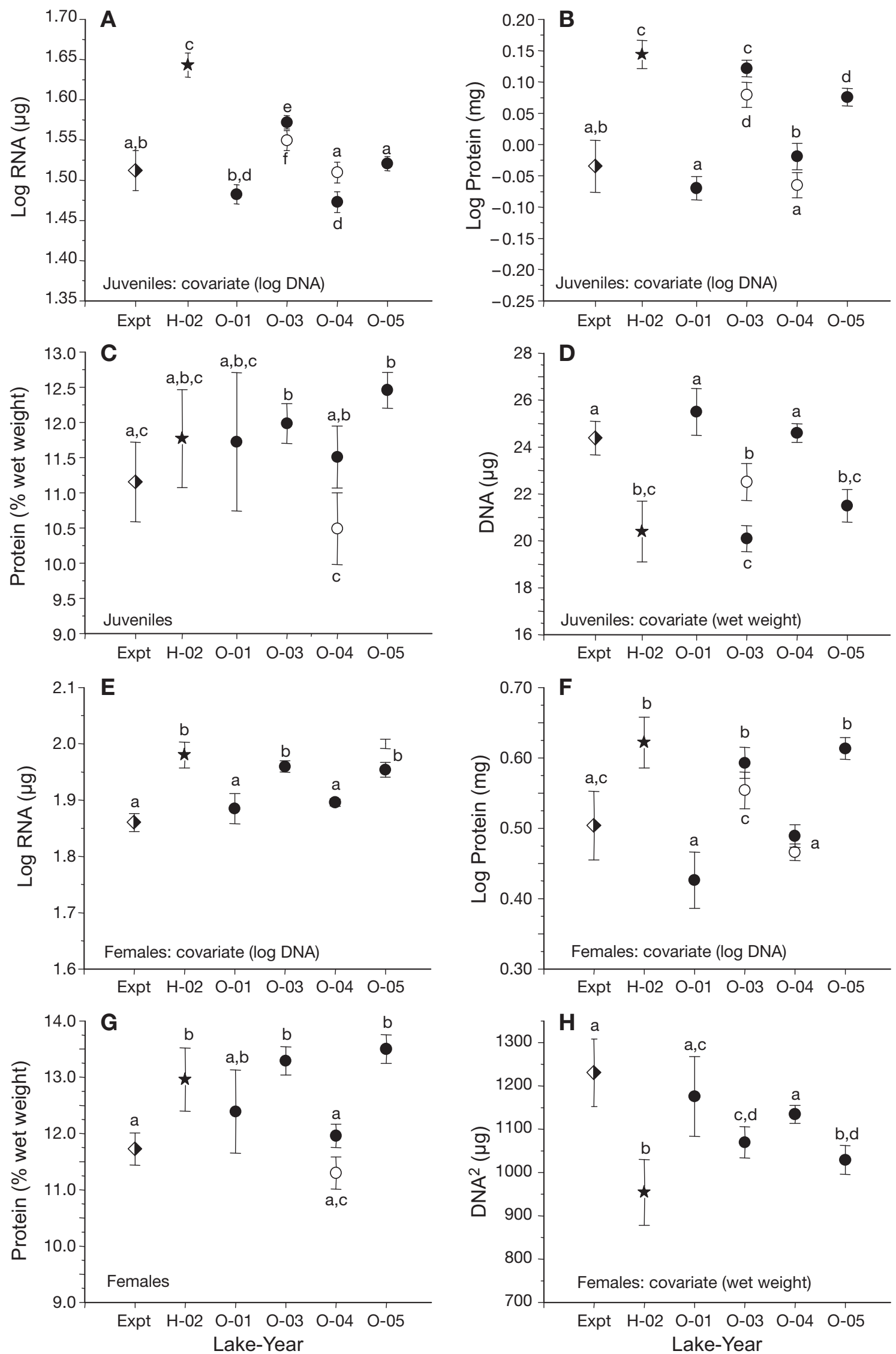
No inshore-offshore trends were observed in 2005. In 2001, the data were insufficient to test for spatial patterns.

Other habitat differences were captured by dividing the lake into quadrants along the main north-south and east-west axes of the lake. Data for all years were combined and the similarity of each index across quadrants assessed. In juveniles, log RNA (cov DNA) showed some differences between the east and west of the lake in 2004, and between the north and south in 2005 (Fig. 5); however, no general pattern was observed among the quadrants. The NE log protein (COV log DNA) was high and the corresponding DNA (cov weight) low, compared with the other quadrants (Fig. 5B,D). These latter 2 patterns were not dependent on a single year. \%protein was lowest in the SE quadrant (Fig. 5C), but was driven solely by the 2004 data. In females, all indices differed significantly. Indices indicating better mysid condition tended to occur in the north, particularly the northeast, and those indicating poorer condition in the south, particularly the southeast (Fig. 5E-H). However, the 2004 data drove the patterns, which disappeared if these data were removed.

Lipids. Mature, non-gravid females had a similar total lipid content (\% dry wt) in 2001 and 2003: 36.1 \pm $4.5 \%(\mathrm{n}=10)$ and $36.8 \pm 1.0 \%(\mathrm{n}=91)$, respectively. Lipid content decreased significantly in 2004 and again in 2005 to $35.3 \pm 1.5 \%(\mathrm{n}=29)$ and $31.5 \% \pm 1.9 \%$ $(\mathrm{n}=31)$, respectively.

No significant correlations were observed between the 4 nucleic acid and protein indices and the 4 individual FA in adult females (Table 2). However, the sum of EPA + DHA was significantly associated with the adjusted means of log RNA (cov log DNA), and closely related to $\log$ protein ( $\mathrm{Cov} \log \mathrm{DNA})(0.05<\mathrm{p}<0.10)$. Significant correlations were observed in juvenile mysids between the adjusted means of log RNA (cov log DNA) and EPA and SAFA; ALA was also close $(0.05<\mathrm{p}<0.10)$. Log protein (cov log DNA) approached significant associations with EPA $(0.05<\mathrm{p}<0.10)$ and SAFA $(0.05<\mathrm{p}<0.10)$ and was significantly correlated with the sum of EPA + DHA. DNA (cov wet weight) had a significant negative association with EPA + DHA and strong, negative but not significant, associations with EPA $(r=-0.898)$ and SAFA $(r=-0.888)$.

\section{Mysid autumn egg ratios}

The adjusted mean number of eggs carried by the same size female, as determined by ANCOVA, declined from a high of $33.0 \pm 0.7$ in 2003 to $28.7 \pm 0.9$ in 2004 and $27.7 \pm 0.8$ in 2005 . Tukeys post-hoc comparisons indicated that the decline was significant at each step.

\section{Zooplankton biomass}

When total water column biomass was plotted against bottom depth, zooplankton biomass increased sharply to $\sim 1.5 \mathrm{~g}$ dry wt $\mathrm{m}^{-2}$ at stations located beyond the $120 \mathrm{~m}$ bottom depth contour (Fig. 6). Of the 7 zooplankton biomass estimates for locations beyond bottom depths of $120 \mathrm{~m}, 6$ were between 1.3 and $2.1 \mathrm{~g}$ dry wt $\mathrm{m}^{-2}$ while 1 was low at $0.5 \mathrm{~g}$ dry wt $\mathrm{m}^{-2}$. No striking inter-annual differences were observed across the 2001 to 2005 time period, suggesting that total zooplankton biomass did not differ greatly amongst these years. A variation on this pattern did occur in 2004: zooplankton biomass at half of the inshore stations (north shore) was high and equivalent to that offshore, a result of strong upwelling events around the lake in October of that year (GLSEA 2007).

Fig. 5. Mysis diluviana. Nucleic acid and protein indices (autumn adjusted means \pm 2 SE) of juveniles (A-D) and adult female (E-H) individuals from the geographical quadrants of Lake Ontario: NE (northeast), NW (northwest), SE (southeast), and SW (southwest). The significant trends are presented for each nucleic acid and protein index. The effect of geoposition (quadrant) was tested within each year (2003 to 2005) and across all years. The log RNA with the covariate log DNA of juvenile mysids did not show significant differences among quadrants, but did show significant differences between the northern and southern halves of the lake and, in 2004, the eastern and western sides of the lake (A). Significantly different values have been assigned different letters (a,b, w, $\mathrm{x}$ ) 

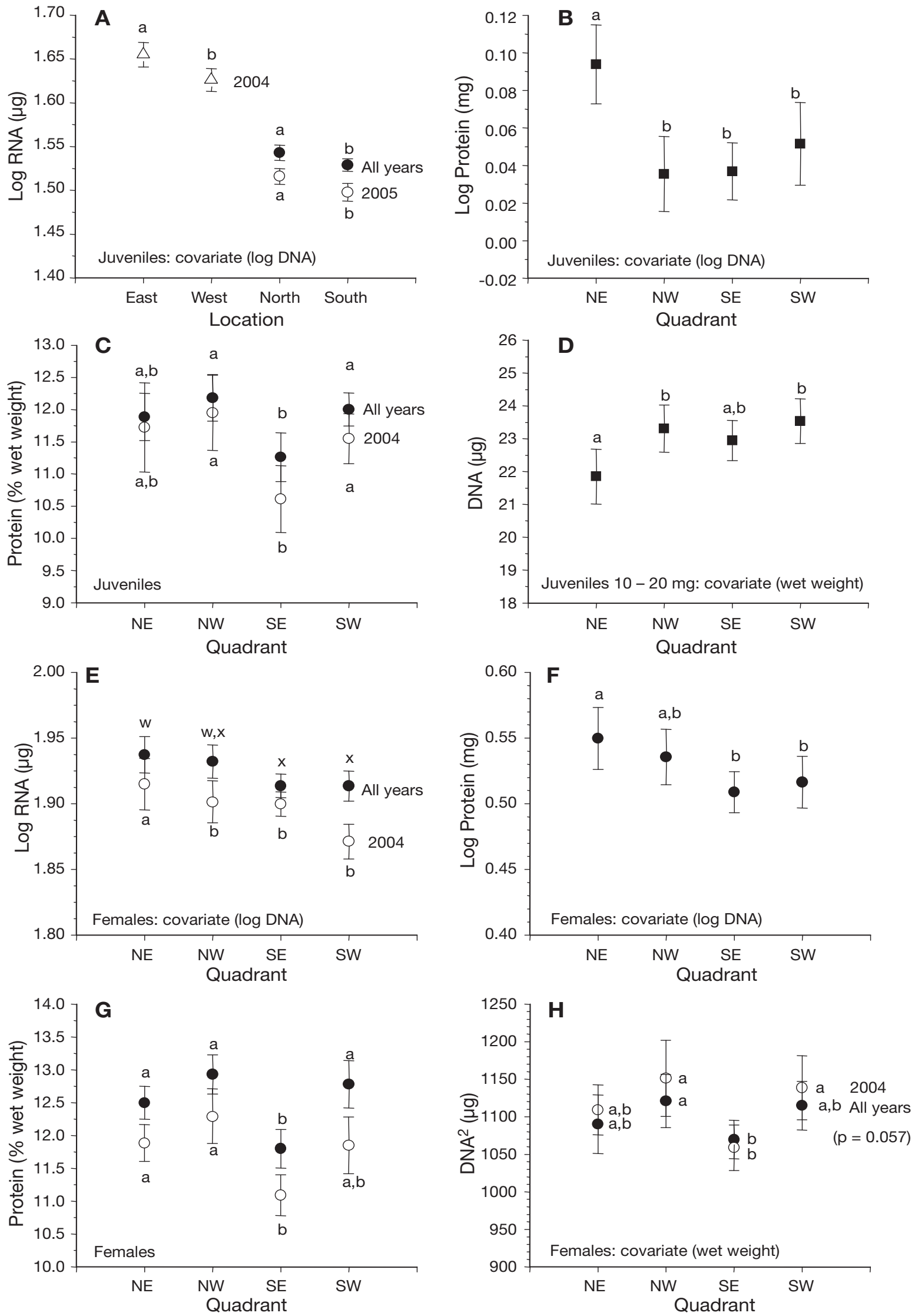


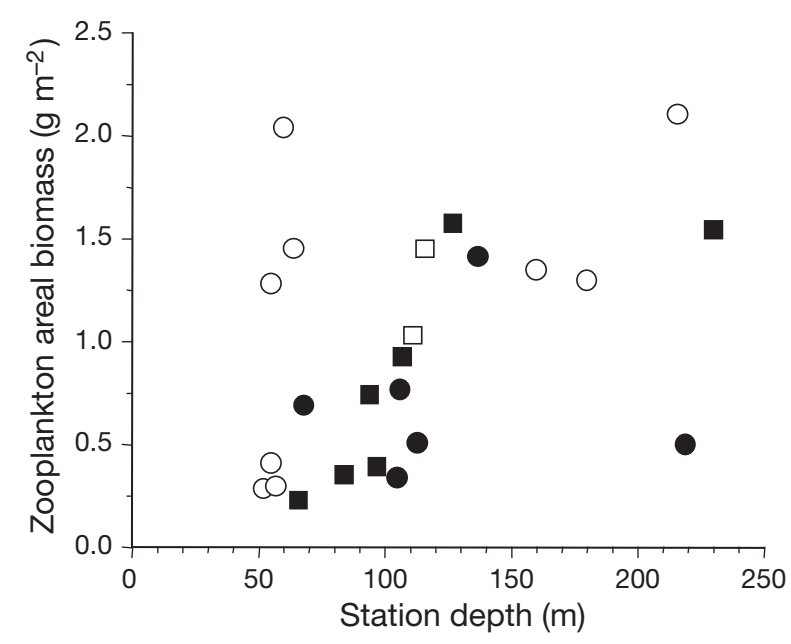

Fig. 6. Zooplankton biomass $\left(\mathrm{g} \mathrm{m}^{-2}\right)$ in the entire water column across the bottom-depth gradient of Lake Ontario; changes in October to early November. Samples were collected with duplicate, vertical net hauls (153 $\mu \mathrm{m}$ mesh) from both northern and southern sites either along the length of the lake (2003 to 2005) or only from the hypolimnion at 2 deep sites (2001). The 2001 data were extrapolated to the entire

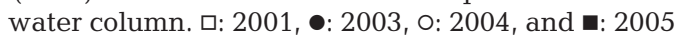

\section{DISCUSSION}

\section{Biochemical growth indices}

Nucleic acid and protein measures are good indices for the assessment of Mysis diluviana condition in field situations. The Lake Ontario autumn field data demonstrate that RNA (cov DNA), protein (cov DNA) and DNA (cov wet weight) have a sufficient range and sensitivity to reveal a gradient of conditions in metabolic activity. Over the $4 \mathrm{yr}$ of the study, significant differences were detected in these indices among years and among locations in the lake within years. \%protein, however, did not show similarly clear differences among years. Only juveniles in the inshore regions in 2004 and adult females in both the inshore and offshore regions in 2004 had a significantly lower protein content than in other years. Data from the laboratory growth experiments by Johannsson et al. (2008) were also lower and similar to our 2004 values. The \%protein data from Lake Ontario were variable, likely due to the process of 'growth by moulting', where individuals expand their new exoskeleton with water when they moult and then replace the water with tissue as they grow. \% protein showed promise as an indicator in the experimental work by Johansson et al. (2008), as it increased significantly from $11.3 \%$ under low growth rates to $12.8 \%$ with higher growth rates. The high variability in \%protein observed, which is likely related at least in part to the manner of growth, reduces the potential of \%protein to detect finer differences in condition; however, it is still important in detecting or confirming particularly poor growth conditions. Although not expressly studied, Johannsson et al. (2008) did not observe moult stage-related changes in the othervariables.

RNA/protein has also been used as an index of potential growth, but we have not included it in the recommended suite of indicators (Fig. 1). RNA/protein has shown significant relationships with protein synthesis and growth rates (Houlihan et al. 1993, Smith et al. 2000); however, the response is not always observed (Smith et al. 2000) and laboratory studies with Mysis diluviana provide further cause for caution in using this index. Mysids fasted for $11 \mathrm{~d}$ exhibited no decline in RNA/protein although RNA/DNA and protein/DNA ratios fell during this period (Schlechtriem et al. 2008b), indicating that RNA and protein fell in tandem. Ratios in which both components can fluctuate can be misleading. Similarly, in $M$. diluviana feeding experiments over a range of low growth rates, RNA/protein and specific growth rate showed no correspondence (Johannsson et al. 2008). Mysid condition was not constant throughout the lake, but could vary between inshore (<120 m bottom depth) and offshore regions and among different quadrants of the lake. Johannsson (1995) observed a movement of mysids from shallower ( $<100 \mathrm{~m}$ bottom-depth) to deeper water as the growing season (May to November) progressed, and proposed 2 hypotheses to explain this pattern: (1) higher size-selective fish predation in the inshore regions may have depressed mysid abundance and selected for smaller-sized individuals, and (2) mysids may have emigrated offshore. Emigration could be a response to predation pressure or a food resource gradient. Similar increases in offshore density and biomass were observed during the 2002 to 2005 study (O. E. Johannsson \& K. L. Bowen unpubl. data). The condition indices presented here may shed some light on the second hypothesis. Generally, the nucleic acid and protein indices indicated that mysids were in better condition in the offshore regions. The 2 exceptions involved measures of log RNA (cov log DNA). Temperature differences can alter RNA concentration (Buckley 1982), with RNA increasing linearly as temperature decreased between 12.7 and $4.2^{\circ} \mathrm{C}$ in Mysis diluviana (Johannsson et al. 2008). Low N/P food resources (Acharya et al. 2004) can also induce increases in RNA without concomitant growth. Therefore, differences in RNA must be substantiated by examining trends in the other indicators. The higher RNA levels in inshore females in 2005 are not substantiated by any of the other indices, and likely do not indicate an enhanced condition.

Similarly, in the case of juveniles in 2004, the other condition indices suggest that animals were in better condition in the offshore regions, although higher RNA content was observed in inshore mysids. Upwelling was persistent and circled much of the lake in October 2004, pushing cooler hypolimnetic water into the inshore 
areas (GLSEA 2007). Juvenile mysids have a temperature preference of $\sim 12^{\circ} \mathrm{C}$ (B. Boscarino, pers. comm.), which takes them into the metalimnion at night in the summer and into surface waters in the autumn. With cold waters near the surface in the inshore regions in October 2004, juvenile mysids in inshore regions likely experienced lower mean diel temperatures than those in the offshore regions, and correspondingly had higher RNA levels than those offshore. Adults, however, may not have been affected to a significant degree, as they have a lower temperature preference $\left(6\right.$ to $\left.8^{\circ} \mathrm{C}\right)$ and generally remain deeper in the water column than juveniles (Boscarino et al. 2007). Therefore, they are normally found in cooler waters, inshore and offshore. Overall, the data indicate that mysid condition in the offshore regions is better than inshore in some but not all years. The potential of improved condition, likely through access to better food resources, may provide an incentive for mysids to move offshore. Whether this is sufficient to promote a general pattern of movement offshore in all years is not clear. It may reinforce other pressures which encourage migration. Thus, food resources may play a role in this behaviour, at least in the autumn, and mysids which move offshore have a statistically higher probability of being in better condition. Additional confirmation should now be sought from spring and summer samples.

Overall, across years, juvenile mysids in the northern half of the lake, particularly the NE quadrant, were in better condition, as indicated by all 4 indices, than mysids in the southern part of the lake. It is not clear why the northern side of the lake was more favorable to juvenile mysids in autumn. On the other hand, location within the lake only affected adult females in 2004. These females were in poorer condition in the southern part of the lake, particularly the SE quadrant. Both the juvenile and female nucleic acid data from 2004 were more variable than those from other years. It would appear that 2004 was a difficult year for many mysids, particularly in the southern part of the lake.

Females exhibited strong north-south differences in condition only in 2004; thus, the cause should be unique to that year. 2004 was marked by strong upwelling throughout October. Cold hypolimnetic waters were forced up the northern side of the lake and zooplankton accumulated in these waters, reaching a total biomass similar to that offshore (Fig. 6). In these cold waters, the vertical ascent of larger mysids would have been limited by light (and/or predators) but not by temperature. Therefore, mysids at all bottom depths potentially had access to high levels of zooplankton biomass. At the same time, epilimnetic water would have been pushed to the south, deepening the epilimnion on the southern side of the lake. This may have presented a thermal barrier to larger mysids, which prefer waters of 6 to $8^{\circ} \mathrm{C}$ (Boscarino et al. 2007), limiting their vertical migration. Light diminishes with depth and mysid feeding efficiency diminishes with the loss of light (Ramcharan \& Sprules 1986). Thus, the feeding potential of adult mysids may have increased in the north and decreased in the south. We cannot dismiss the possibility that upwelling influenced the spatial patterns in mysid condition in 2004.

Thus, distinct spatial patterns in condition indices can occur in Mysis diluviana in Lake Ontario between (1) the inshore and offshore, (2) the northern and southern reaches of the lake, and (3) in response to upwelling events. These patterns need to be taken into account in setting the objectives of and design any future monitoring of the lake.

Maturation can affect the nucleic acid ratios (e.g. reviewed in Bulow 1987) and October/November is the dominant reproductive period for mysids in Lake Ontario (Johannsson 1992). Males contained $8 \%$ more DNA, or cells, than females of the same size. This value is in the range expected for species where males mate with numerous partners during the reproductive period and, consequently, invest substantial resources in sperm production (e.g. Stockley et al. 1997). However, the RNA content per cell of larger (older?) males declined, as indicated by the low RNA concentrations relative to protein and the lower than expected RNA/DNA ratios. Schlechtriem et al. (2008b) described the decline in RNA/DNA and RNA/protein with fasting in juvenile mysids. Normally, RNA/DNA ratios increase with body size (see also Nordin 2005). RNA/DNA ratios $\leq 2$, as seen in the field data of the present study, were associated with prolonged fasting at the largest body size observed (24 mg) in the study of Schlechtriem et al. (2008b). Two possible explanations exist: either the larger males contain a lot of sperm, which has a low RNA content, or the larger males are senescing after reproduction. Since (1) the higher DNA content of males is consistent across all body sizes, (2) the drop in RNA/DNA is greater than could be accounted for if all of the additional cells were sperm and had little or no RNA, and (3) no decline occurred in mature females, the second hypothesis is supported. The decline in RNA in larger males indicates a marked decrease in cellular activity, growth and protein synthesis; symptoms characteristic of a physiological decline. This conclusion is consistent with the observation of Morgan \& Beeton (1978) in Lake Michigan that, after males reproduce, they do not moult again and eventually die off. Therefore, if males were to be included in a monitoring program which involved assessing their physiological condition, their reproductive period, state of maturation and decline would have to be taken into account.

Sample size and distribution are important considerations in designing a monitoring program. We found that 
20 to 30 individuals could define the status of a group, as was demonstrated in the geoposition comparisons for each life stage. Thus, the total number of mysids that should be examined in a lake is a function of the number of life stages examined and potential spatial variation within the lake. For Lake Ontario, a minimum of 160, but preferably 200 to 240 individuals, can capture mysid condition and its spatial variability, including 2 life stages within 4 quadrants distributed over the depth range of the mysid distribution. The mysids should also be collected over the whole size range present in order to improve the sensitivity of the ANCOVA.

\section{Comparisons with other mysid nucleic acid studies}

How do the field data of the present study correspond with laboratory studies on the response of nucleic acid and protein indices to a range of experimental feeding regimes, including fasting, in Mysis diluviana? Schlechtriem et al. (2008b) described declines in RNA and protein relative to DNA with fasting in juvenile mysids, the declines increasing with time and temperature. Schlechtriem et al. (2008b) gave the relationships between RNA/DNA and protein/DNA ratios with body wet weight for both the day of capture and $11 \mathrm{~d}$ fasted animals at 3 and $8^{\circ} \mathrm{C}$. Mean diel temperature experience of juvenile mysids in October to early November in Lake Ontario is between 5 and $7^{\circ} \mathrm{C}$, depending on the epilimnetic temperature (GLSEA 2007), and time in the upper water column was estimated as $12 \mathrm{~h} \mathrm{~d}^{-1}$. Ratios in the study by Schlechtriem et al. (2008b), recalculated to $6^{\circ} \mathrm{C}$, were: 2.34 and 1.95 for RNA/DNA, and 0.079 and 0.066 for protein/DNA in freshly caught and fasted individuals, respectively. In the present study, ratios for individuals weighing between 14.5 and $16.5 \mathrm{mg}$ were averaged for each year in Lake Ontario. Ratios for 2003 were similar to those of the 'freshly caught' mysids (RNA/DNA $=2.28$, protein $/ \mathrm{DNA}=0.083$, $\mathrm{n}=20$ ), while individuals in 2004 had ratios of 2.06 (RNA/DNA) and 0.069 (protein/DNA) $(\mathrm{n}=27)$ : the former index was still significantly higher than that of the fasted mysids, while the latter was not. In 2001, only 5 individuals fell in this size range and the large error term ensured that the index values were not significantly different from fasted or normal animals: 2.11 (RNA/DNA) and 0.07 (protein/DNA). In 2005, the RNA/DNA (2.06) ratio was intermediate and significantly different from both the freshly caught and fasted mysids, while the protein/DNA (0.086) ratio was higher than that of the freshly caught mysids $(n=11)$. These comparisons confirm the normal condition of mysids in 2003 and the poor condition of mysids in 2004.

Johannsson et al. (2008) examined responses of nucleic acid and protein indices of Mysis diluviana fed
Artemia or Cyclop-eeze ${ }^{\circledR}$ (freeze dried copepods) for 3 to $6 \mathrm{wk}$ to changes in temperature and feeding regime. We compared the nucleic acid and protein indices of the study by Johanssen et al. (2008) to those from the present study (Fig. 4A,B). For both females and juveniles, the experimental indices from well-fed animals experiencing mean diel temperatures between 4.2 and $6.7^{\circ} \mathrm{C}$ were similar to those observed in the present study in 2001 and 2004, with the exception of juvenile log RNA (cov DNA). In the experimental study, RNA had increased at the highest food ration without a concurrent increase in growth rate, and this may explain the discrepancy. Johannsson et al. (2008) observed that experimental ad libitum fed mysids had lower than expected growth rates based on field estimates over the April to October period: e.g. $0.41 \% \mathrm{~d}^{-1}$ (10 mg juvenile) and $0.15 \% \mathrm{~d}^{-1}$ (30 mg young adult) compared to 1.0 to $0.6 \% \mathrm{~d}^{-1}$ for 10 and $30 \mathrm{mg}$ mysids in the field. These comparisons suggest that the animals in 2004, and perhaps 2001, of the present study were growing at similarly low rates. This result is in agreement with the comparisons to the fasting experiments above. We do not yet know the growth rates associated with the 2003 and 2005 mysid condition indices; however, the similarity of these indices to those from Lake Huron 2002 suggest that these values are within the normal range.

Given that mysids exhibit distinct patterns in nucleic acid and protein indices over the years, do we see similar patterns in their food supply or food quality? In addition, are there similar patterns in egg production as observed by Saiz et al. (1998) in the copepod Acartia grani? Over $90 \%$ of the biomass consumed by mysids in the autumn is composed of zooplankton (Johannsson et al. 2001). No distinct difference occurred in the areal biomass of zooplankton across the years of this study. Percent total lipid of mature, non-gravid females, another index of food quantity, declined from 2003 through 2004 and 2005. Neither food quantity pattern across years fits that of the nucleic acid and protein indices, suggesting that food quantity alone was not responsible for the inter-annual patterns in these indices. Food quality may differ across years in a pattern similar to that observed in nucleic acid and protein indices. Pearson's correlations indicated a number of significant and nearly significant $(0.05<\mathrm{p}>0.1)$ associations between nucleic acid and protein indices and concentrations of EPA, SAFA and (EPA + DHA).

Schlechtriem et al. (2008a) recently showed that DHA is conserved during fasting, which may explain its lack of strong direct associations with nucleic acid and protein indices. Relationships between nucleic acid and protein indices and EFA composition require more study to determine whether these associations hold and which lipid profiles are most correlated with somatic growth. The trends in nucleic acid and protein 
indices did not extend to patterns in egg production per female mysid. Egg production was high in 2003 and declined through 2004 and 2005, roughly mirroring the pattern in \% total lipids, while nucleic acid and protein indices in mature, non-gravid females were high in 2003 and 2005. More years of data are needed to confirm the relationships between fecundity and total lipids and between nucleic acid and protein indices and EFA, and the lack of correspondence between the 2 groups. However, if they hold, this brings into question inter-annual variation in egg quality.

In conclusion, nucleic acid and protein indices are suitable for monitoring the condition of Mysis diluviana in the field. They express a sufficient range and sensitivity to detect differences among years and different habitats within Lake Ontario. Years with $M$. diluviana in 'poor condition' had nucleic acid and protein indices similar to laboratory values of animals with low growth rates, values which were slightly above the indicators of fasting but below 'normal' values found in the lake. The normal values were similar to those in years with putative 'good condition'. Inshore mysids tended to be in poorer condition than offshore mysids in 2 of the 3 yr for which we have sufficient data. This supports the hypothesis that improved food resources may be partly involved in the movement of mysids offshore. Neither total zooplankton areal biomass and \% total lipids in mature, non-gravid females (2 measures of food quantity), nor number of eggs per female were related to nucleic acid and protein-based indices of mysid condition; however, key EFA and SAFA had interesting associations which suggest the importance of food quality and the need for further study.

Acknowledgements. We thank J. Gerlofsma, S. Litwiller, M. Drebenstedt, H. Ahman, C. Schlechtriem, T. Spencer, C. Chu, T. Bonnell, K. Bonnell and M. Chew for help in sampling and sample processing. We thank the captains and crews of Canadian Coast Guard Ships (CCGS) 'Griffon', 'Simcoe' and 'Limnos', and Technical Operations, Environment Canada who were extremely helpful in the collection of these samples. We thank D. McDonald for providing space at the Rosenstiel School for Marine and Atmospheric Sciences during the writing of this manuscript, and to J. Fitzpatrick for discussions on male maturity. We particularly thank L. Rudstam for organizing the mysid symposium at the 2007 ASLO meeting. The funding sources for this program include Fisheries and Oceans, Canada both directly (O.E.J., K.L.B.) and through the Environmental Strategic Science Research Fund (O.E.J., M.T.A.), the Ontario Ministry of Natural Resources through the Canadian-Ontario Agreement (O.E.J., K.L.B., M.T.A.), the Great Lakes Fishery Commission (grant \#000585-052003) (M.T.A., O.E.J.), and Environment Canada (M.T.A.).

\section{LITERATURE CITED}

Acharya K, Kyle M, Elser JJ (2004) Biological stoichiometry of Daphnia growth: an ecophysiological test of the growth rate hypothesis. Limnol Oceanogr 49:656-665

Adare KI, Lasenby DC (1994) Seasonal changes in the total lipid content of the opossum shrimp, Mysis relicta (Malacostraca: Mysidacea). Can J Fish Aquat Sci 51:1935-1941

Audzijonyte A, Väinolä R (2005) Diversity and distributions of circumpolar fresh- and brackish-water Mysis (Crustacea: Mysida): descriptions of $M$. relicta Lovén, 1862, M. salemaai $\mathrm{n} \mathrm{sp}, M$. segerstralei $\mathrm{n} \mathrm{sp}$ and $M$. diluviana $\mathrm{n} \mathrm{sp}$, based on molecular and morphological characters. Hydrobiologia 544:89-141

> Bergeron JP (1997) Nucleic acids in icthyoplankton ecology: a review, with emphasis on recent advances for new perspectives. J Fish Biol 51(Suppl A):284-302

Boscarino BT, Rudstam LG, Mata S, Gal G, Johannsson OE, Mills EL (2007) The effects of temperature and predatorprey interactions on the migration behavior and vertical distribution of Mysis relicta.Limnol Oceanogr 52:1599-1613

Buckley LJ (1979) Relationships between RNA/DNA ratio, prey density and growth rate in Atlantic cod (Gadus morhua) larvae. J Fish Res Board Can 36:1497-1502

Buckley LJ (1982) Effects of temperature on growth and biochemical composition of larval winter flounder Pseudopleuronectes americanus. Mar Ecol Prog Ser 8:181-186

Buckley LJ, Bulow FJ (1987) Techniques for the estimation of RNA, DNA, and protein in fish. In: Summerfelt RC, Hall GE (eds) Age and growth of fish. Iowa State University Press, Ames, pp 345-354

Bulow FJ (1987) RNA:DNA ratios as indicators of growth in fish: a review. In: Summerfelt RC, Hall GE (eds) Age and growth of fish. Iowa State University Press, Ames, pp 45-64

Cooley JM, Moore JE, Geiling WT (1986) Population dynamics, biomass, and production of the macrozooplankton in the Bay of Quinte during changes in phosphorus loadings. In: Minns KC, Hurlley DA, Nicholls KH (eds) Project Quinte: point-source phosphorus control and ecosystem response in the Bay of Quinte, Lake Ontario. Can Spec Publ Fish Aquat Sci 86:166-176

> Dahlhoff EP, Menge BA (1996) Influence of phytoplankton concentration and wave exposure on the ecophysiology of Mytilus californianus. Mar Ecol Prog Ser 144:97-107

Dermott R, Geminiuc M (2003) Changes in the benthic fauna of Lake Ontario 1990-1995, with local trends after 1981. In: Munawar M (ed) The state of Lake Ontario ecosystem (SOLO) - past, present and future. Backhuys Publishers, Leiden, p 321-345

> Dermott R, Munawar M, Carou S, Bonnell R, Niblock H (2005) Is sediment or pseudofaeces toxicity responsible for the decline of the amphipod Diporeia hoyi in Lakes Erie and Ontario? Aquat Ecosyst Health Manag 8:11-20

Foster AR (1990) Growth and protein turnover in fish. PhD thesis, University of Aberdeen

Foster AR, Houlihan DF, Hall SJ, Burren LJ (1992) The effects of temperature acclimation on protein synthesis rates and nucleic acid content of juvenile cod (Gadus morhua L). Can J Zool 70:2095-2102

Gal G, Rudstam LG, Mills EL, Lantry JR, Johannsson OE, Green CH (2006) Mysid and fish zooplanktivory in Lake Ontario: quantification of direct and indirect effects. Can J Fish Aquat Sci 63:2734-2747

GLSEA (2007) Great Lakes Surface Environmental Analysis, National Oceanic and Atmospheric Administration. Available at: http://coastwatch.glerl.noaa.gov/glsea/movies, accessed July 2007

$>$ Hondorp DW, Pothoven SA, Brandt SB (2005) Influence of Diporeia density on diet composition, relative abundance, and energy density of planktivorous fishes in southeast Lake Michigan. Trans Am Fish Soc 134:588-601 
Houlihan DF, Mathers EM, Foster AR (1993) Biochemical correlates of growth rate in fish. In: Rankin JC, Jensen FB (eds) Fish Ecophysiology. Chapman \& Hall, London, p 45-71

Hoyle JA, Casselman JM, Dermott R, Schaner T (2003) Resurgence and decline of lake whitefish (Coregonus clupeaformis) stocks in eastern Lake Ontario, 1972 to 1999. In: Munawar M (ed) The state of Lake Ontario ecosystem (SOLO) - past, present and future. Backhuys Publishers, Leiden, p 475-491

Johannsson OE (1992) Life history and productivity of Mysis relicta in Lake Ontario. J Gt Lakes Res 18:154-168

Johannsson OE (1995) The response of Mysis relicta population dynamics and productivity to spatial and temporal gradients in Lake Ontario. Can J Fish Aquat Sci 52: 1509-1522

Johannsson OE (2003) Zooplankton community structure and function in Lake Ontario. In: Munawar M (ed) The state of Lake Ontario ecosystem (SOLO) - past, present and future. Backhuys Publishers, Leiden, p 221-256

Johannsson OE, Dermott R, Graham DM, Dahl JA, Millard ES, Myles DD, LeBlanc J (2000) Benthic and pelagic secondary production in Lake Erie after the invasion of Dreissena spp. with implications for fish production. J Gt Lakes Res 26:31-54

> Johannsson OE, Leggett MF, Rudstam LG, Servos MR and others (2001) Diet of Mysis relicta in Lake Ontario as revealed by stable isotope and gut content analysis. Can J Fish Aquat Sci 58:1975-1986

Johannsson OE, Bowen KL, Wood CM, Smith RW, Chu C, Rudstam LG, Boscarino B (2008) Relating nucleic acid and protein indices to growth in Mysis relicta: ration, cycling temperature, and metabolism. Aquat Biol 4:33-46

Lowry OH, Rosebrough NJ, Farr AL, Randall RJ (1951) Protein measurement with folin phenol reagent. J Biol Chem 193:265-275

- Mathers EM, Houlihan DF, McCarthy ID, Burren LJ (1993) Rates of growth and protein synthesis correlated with nucleic acid content in fry of rainbow trout, Oncorhynchus mykiss: effect of age and temperature. J Fish Biol 43: 245-263

McNickle GG, Rennie MD, Sprules WG (2006) Changes in benthic invertebrate communities of South Bay, Lake Huron following invasion by zebra mussels (Dreissena polymorpha), and potential effects on lake whitefish (Coregonus clupeaformis) diet and growth. J Gt Lakes Res 32:180-193

Mills EL, Dermott R, Johannsson OE, Munawar M and others (2006) Developing the next generation of Great Lakes lower food web assessment tools: status of the Lake Ontario food web in a changing ecosystem. 2003 Lake Ontario lower aquatic food web assessment (LOLA), final report to EPA, Duluth. Available at: http://www.epa.gov/ glnpo/lakeont/lola/lola2006appendix.pdf

Morgan MD, Beeton AM (1978) Life history and abundance of Mysis relicta in Lake Michigan. J Fish Res Board Can 35: 1165-1170

Munro HN, Fleck A (1966) The determination of nucleic acids. Methods Biochem Anal 14:113-176

Nalepa TF, Fanslow DL, Foley AJ III, Lang GA, Eadie BJ, Quigley MA (2006) Continued disappearance of the benthic amphipod Diporeia spp. in Lake Michigan: Is there evidence for food limitation? Can J Fish Aquat Sci 63: $872-890$

Nordin LJ (2005) The impact of Bythotrephes longimanus on the diet, growth, and energy storage of Mysis relicta in central Ontario lakes. MSc thesis, University of Waterloo, Waterloo
O'Gorman R, Elrod JH, Owens RW, Schneider CP, Eckert TH, Lantry BF (2000) Shifts in depth distributions of alewives, rainbow smelt and age-2 lake trout in southern Lake Ontario following establishment of dreissenids. Trans Am Fish Soc 129:1096-1106

Patalas K (1969) Composition and horizontal distribution of crustacean plankton in Lake Ontario. J Fish Res Board Can 26:2135-2164

> Pothoven SA, Nalepa TF, Schneeberger PJ, Brandt SB (2001) Changes in diet and body condition of lake whitefish in southern Lake Michigan associated with changes in benthos. N Am J Fish Manag 21:876-883

Ramcharan CW, Sprules WG (1986) Visual predation in Mysis relicta Loven. Limnol Oceanogr 31:414-420

Rand PS, Stewart DJ, Lantry BF, Rudstam LG and others (1995) Level and effect of whole-lake invertebrate predation by pelagic planktivores in lakes Michigan and Ontario. Can J Fish Aquat Sci 52:1546-1563

Saiz E, Calbet A, Fara A, Berdalet E (1998) RNA content of copepods as a tool for determining adult growth rates in the field. Limnol Oceanogr 43:465-470

Schlechtriem C, Arts MT, Johannsson OE (2008a) Effect of long-term fasting on the use of fatty acids as trophic markers in the opossum shrimp Mysis relicta-a laboratory study. J Gt Lakes Res 34:143-152

Schlechtriem C, Johannsson OE, Bowen KL, Smith RW, Arts MT (2008b) Effect of fasting under different temperature conditions on nucleic acid ratios in the opossum shrimp Mysis relicta: a calibration approach. J Gt Lakes Res 34: 461-471

Schmidt EE, Schibler U (1995) Cell size regulation, a mechanism that controls cellular RNA accumulation: consequences on regulation of the ubiquitous transcription factors Oct 1 and NF-Y, and the liver-enriched transcription factor DBP. J Cell Biol 128:467-483

Schmidt G, Thannhauser SJ (1945) A method for the determination of deoxyribonucleic acid, ribonucleic acid and phosphoproteins in animal tissues. J Biol Chem 161:83-89

Smith RW, Houlihan DF, Nilsson GE, Alexandre J (1999) Tissue specific changes in RNA synthesis in vivo during anoxia in crucian carp. Amer J Physiol Regul Integr Comp Physiol 277:R690-R697

Smith RW, Palmer RM, Houlihan DF (2000) RNA turnover and protein synthesis in fish cells. J Comp Physiol [B] 170: 135-144

Stockley P, Gage MJG, Parker GA, Moller AP (1997) Sperm competition in fishes: the evolution of testis size and ejaculate characteristics. Am Nat 149:933-954

Wagner M, Durbin E, Buckley L (1998) RNA:DNA ratios as indicators of nutritional condition in the copepod Calanus finmarchicus. Mar Ecol Prog Ser 162:173-181

- Wagner MM, Campbell RG, Boudreau CA, Durbin EG (2001) Nucleic acids and growth of Calanus finmarchicus in the laboratory under different food and temperature conditions. Mar Ecol Prog Ser 221:185-197

> Walsh MG, Dittman DE, O'Gorman R (2007) Occurrence and food habits of the round goby in the profundal zone of southwestern Lake Ontario. J Gt Lakes Res 33:83-92

Warner D, Rudstam LG, Benoit H, Mills EL, Johannsson OE (2006) Changes in seasonal nearshore zooplankton abundance patterns in Lake Ontario following the establishment of the exotic predator Cercopagis pengoi. J Gt Lakes Res 32:531-542

Watkins JM, Dermott R, Lozano SJ, Mills EL, Rudstam LG, Scharold JV (2007) Evidence for remote effects of dreissenid mussels on the amphipod Diporeia: analysis of Lake Ontario benthic surveys, 1972-2003. J Gt Lakes Res 33: 643-657 